\title{
Underwater Cultural Heritage and Maritime Archaeology in Croatia: An Overview
}

\author{
IRENA RADIĆ RosSI \\ Department of Archaeology, University of Zadar, Croatia
}

\begin{abstract}
Archaeological sites in Croatia's shallow waters are mentioned in written sources from the sixteenth century, and since the eighteenth century they have been used as evidence for the sinking of the Eastern Adriatic coast. It was at the end of the same century that the first Roman shipwreck in Croatian waters was reported. Sponge divers and coral hunters raised archaeological finds from the seabed off the Croatian coast, thus contributing to the creation of many private and monastic collections. Isolated campaigns aimed at protecting underwater cultural heritage began in the 1950s, and by 1970 these efforts became part of a well-organized system. Although the lack of systematic research remains notable, a number of surveys and rescue excavations have enriched our knowledge of ancient seafaring along the Croatian coast and have contributed to the study of the maritime environment. Some well-preserved shipwrecks from classical antiquity and the modern era show excellent potential for the in situ protection and presentation of Croatian underwater cultural heritage.
\end{abstract}

Keywords: underwater archaeology, maritime archaeology, shipwrecks, seafaring, cultural heritage, protection, preservation, Croatia

\section{INTRODUCTION}

Maritime Croatia is composed of 1246 islands, islets, and reefs distributed along a $500 \mathrm{~km}$ long section of the Eastern Adriatic coast. These 500 linear kilometres include $1777 \mathrm{~km}$ of the mainland shore and $4068 \mathrm{~km}$ of insular coastline. The many sheltered inlets, deep bays, protected channels, and straits (Figure 1) created complex seafaring conditions that, in concert with historically dynamic political situations, led to a great number of shipwrecks.

The maritime orientation of the local population through history, both on the mainland and in the islands, is evident in the shallow waters along the coast.
Together with coastal structures that, by isostatic and tectonic movements, now lie below the present sea level, they represent an important part of an underwater cultural heritage that must be researched and protected.

Although an interest in sunken archaeological remains was expressed several centuries ago, an organized system of research, protection, and preservation of Croatian underwater cultural heritage was proposed only in the late 1960s - a time when sponge-diving, coral-hunting, and the development of sport-diving had already caused much damage on the seabed.

The initial enthusiasm expressed by a small group of archaeologists led to 


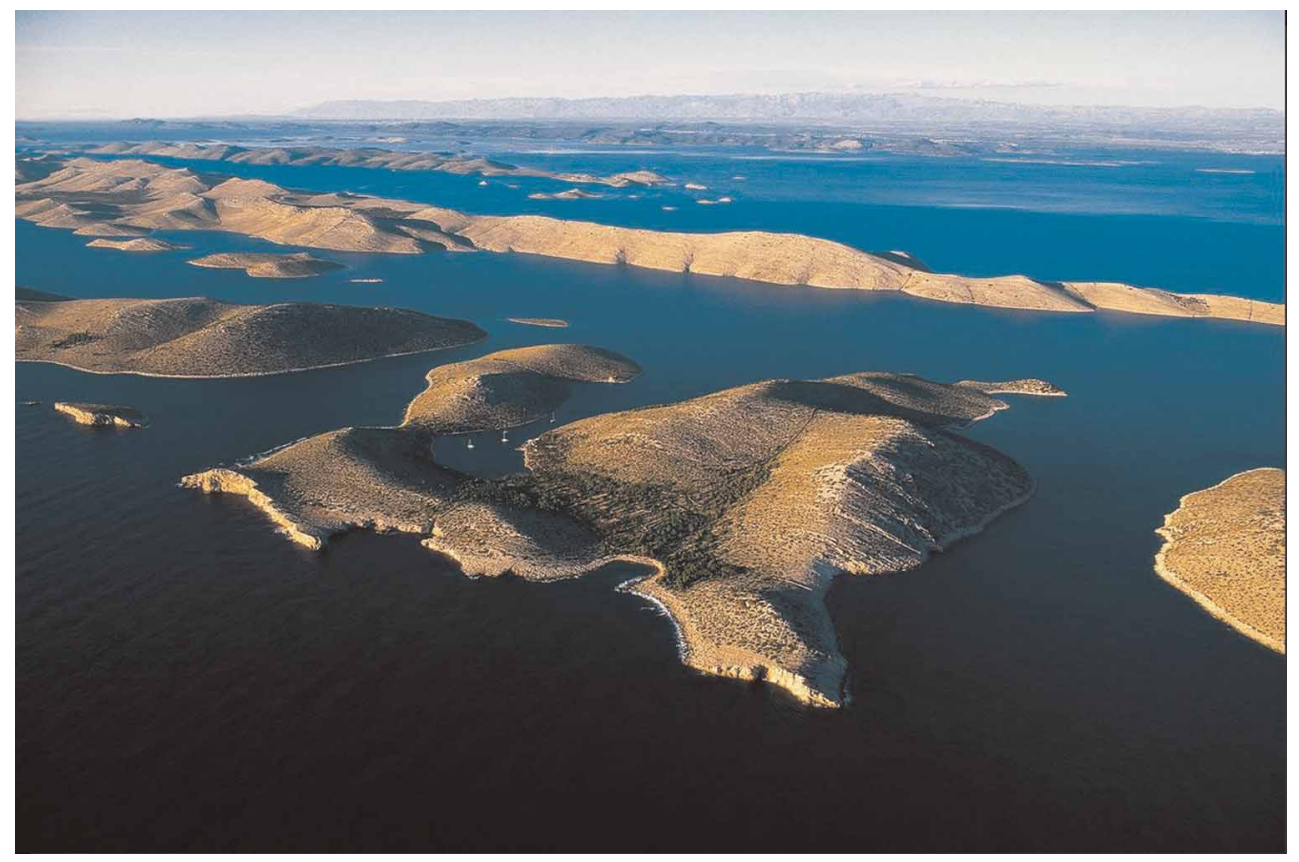

Figure 1. Areal view of the Kornati archipelago in central Dalmatia.

Photo: D. Šarić.

outstanding results which impacted both Croatia and the international scientific community in a very short period of time. Unfortunately, a well-structured system only partially evolved over the ensuing decades, and in the end lost many of its most important features. Even so, an interest in the in situ protection and presentation of underwater archaeological sites has raised an awareness of their value and importance. A specific model of in situ protection, whereby protective cages were positioned over archaeological sites, has proved to be functional over time, but an efficient management of the model requires a more thorough conceptualization and realization.

This article aims to present an overview of the development of maritime archaeology in Croatia and its achievements to the present day through a discussion of some of the most important discoveries and projects. It points out the generally positive evolution of maritime research, but also singles out some of the weak points that should be addressed in a serious manner in the near future.

\section{History}

In his description of the Istrian Peninsula, Pietro Coppo, a famous sixteenth century cartographer and native of Izola (Slovenia), mentioned a number of submerged remains along the coast from the Roman period, including buildings, commercial structures, and ports (Coppo, 1540; Petrić, 2006: 14). In the same period, Venetian senator Zuan Battista Giustiniani, on his way to Dalmatia, described the impressive remains of Cissa, that lay partly on land and partly in the shallow waters of Caska Bay on the island of Pag (Petric, 2006: 14). The ruins were probably famous among the highly educated at the time, 
and this almost certainly accounted for his visit. Similar references that treat the same and other parts of the Croatian coast can be found in an article by Petric (2006: 1415), which concentrates mainly on short descriptions of the visible remains without entering too deeply into historical contexts.

In the eighteenth century, the Italian naturalist Vitaliano Donati linked the submergence of terrestrial archaeological sites along the Eastern Adriatic coast with the change of sea level since ancient times (Donati, 1750). His work was fully supported several decades later by the Italian abbot Alberto Fortis, who during his journey through Dalmatia and neighbouring areas described a number of sites and finds from the Adriatic Sea and inland waters, using them partly to support Donati's theory, mentioning also for the first time a Roman shipwreck (Fortis, 1774).

In 1818, Anton Steinbüchel von Rheinwall, professor of archaeology and director of the Imperial Museum of Vienna, visited Dalmatia and described the sunken sarcophagi along the western waterfront of Vranjic (Steinbüchel, 1820), a small enchanting village situated on the peninsula between Salona, the capital of the Roman province, and the present city of Split where emperor Diocletian erected his famous palace. Convinced that the sarcophagi were found in situ, many authors used them during the nineteenth century to support the idea of relative sea-level changes. In 1854, Mijat Sabljar, curator of the National Museum of Zagreb, drew the first sketches of the already famous underwater finds (Mirnik, 1981: 211, 235).

In 1899, don Frane Bulić, a priest and native of Vranjic who became one of the most famous Croatian archaeologists and promoters of Croatian archaeological heritage in the country and abroad, organized an underwater survey to document in detail the sunken sarcophagi. It was
Croatia's first underwater research campaign, realized with the help of the Central Maritime Government in Trieste and a surface-supplied diver whose time was donated by the state administration. At the end of that campaign a final drawing was produced, and the idea that the sarcophagi lay in situ was proposed (Bulić, 1899, 1900). Although it was the first official underwater archaeological survey along the Croatian coast, it failed to stimulate further underwater research or protection of underwater cultural heritage.

At the end of the nineteenth century surface-supplied diving equipment was introduced to the island of Krapanj near Šibenik (Figure 2). The island's inhabitants, together with those from the neighbouring islands of Zlarin and Murter, were already famous for their sponge diving and coral hunting. Over the next few decades they became the absolute rulers of the seabed, but their lack of understanding of the intrinsic value of archaeological objects and underwater culture heritage in general badly affected the destiny of many shipwrecks. Roman wrecks with cargoes of amphorae or pottery presented the main targets of looting or even pure destruction. Some of the sites discovered in those years were never officially registered, and they subsequently became impossible to identify.

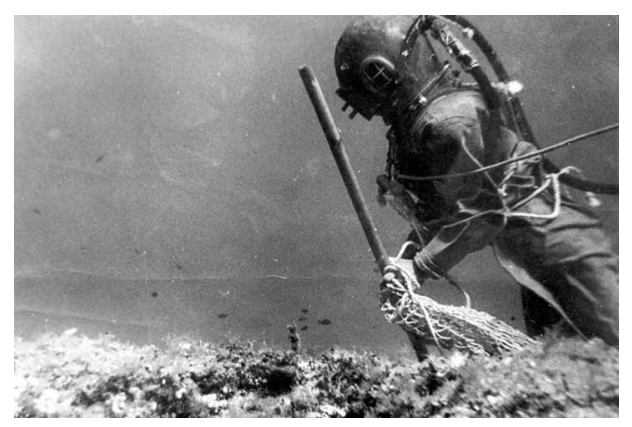

Figure 2. Sponge hunter from Krapanj in action in 1960s. 
The same or similar fate may be surmised for many sites that were heavily looted by sport divers during the first decades after the Second World War; as their discoverers slowly pass away there is nobody left to remember some of the important areas where the sandy or muddy seabed hides interesting archaeological materials.

In 1949, the Maritime Museum in Dubrovnik began the first organized campaign to raise underwater archaeological finds. Curiously, despite the presence of many much older sites, the campaign was directed at an eighteenth-century wreck in the bay of Veliki Molunat south of Dubrovnik (Luetic, 1951). The operation was coordinated from the surface while surface-supplied divers worked on the site. One gun of certain English production, dated to 1788 , together with the results of archival research, suggested that the wreck may have been a Russian sailing ship in the service of the English navy, used to attack Ragusan and French vessels. The campaign continued the following year and restarted again in the late 1950s. Although the project followed no specific methodology, and no archaeologists were present on the site, it was the first demonstration of a scientific interest in the protection and study of underwater cultural heritage in Croatia after the World War II. In 1958, its results were presented at the Second International Congress on Underwater Archaeology held in Albenga, Italy (Nikolanci, 1961: 24).

In the 1960s an interest in researching and protecting underwater cultural heritage spread throughout the entire coast. Efforts flourished first in the centres as Rijeka, where local diving organizations offered strong support to non-diving archaeologists. Interest in the architectural remains in shallow water off Istria was stimulated already at the beginning of the century by Pietro Kandler, Anton Gnirs, and other authors (Petrić, 2006: 20) and later by
Attilio Degrassi, who wrote an influential article on submerged Roman ports (Degrassi, 1955). By the end of the 1960s, the first surveys and rescue excavations were already organized in the main maritime centres, such as Pula, Rijeka, Zadar, Šibenik, Split, Hvar, and Dubrovnik. Although they may be considered a series of isolated attempts, some of their discoveries turned out to be very important for the history of maritime archaeology in Croatia.

In 1967 and 1968, in the area of ancient Aenona or later Nona (present day Nin, north of Zadar), two well-preserved medieval boats were discovered (Brusić, 1969). Three documentation campaigns preceded the raising of the finds in 1974 (Brusic, 1978); these finds were put on display in the local museum after ten years of conservation treatment (Juric et al., 1994) (Figure 3). Tentatively dated to the

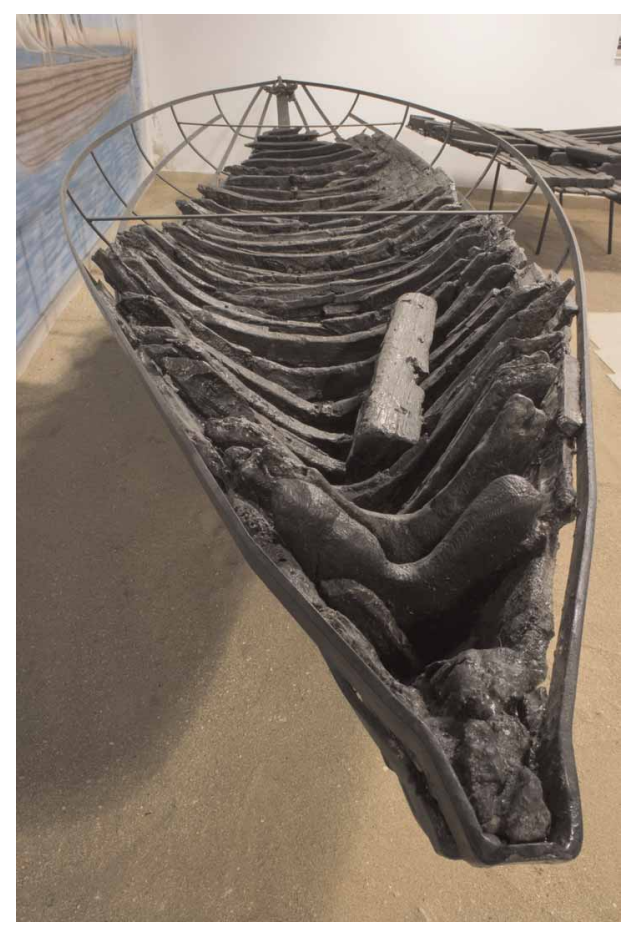

Figure 3. Mediaeval boat Nin 1 displayed in the Museum of Nin Heritage.

Photo: R. Mosković. 
end of the eleventh century or the beginning of the twelfth century, the two boats present an important element in Croatia's national heritage and figure as symbols of navigation in the time of the Kingdom of Croatia (tenth and eleventh centuries). The Nin project figured until recently as the country's only nautical archaeology project that succeeded in the conservation and presentation of the finds.

At the same time, the port of Roman Aenona was discovered in the Bay of Zaton, $2.5 \mathrm{~km}$ distant from present Nin. In 1967, the Cambridge Illyricum Expedition made a short-term survey in the area. However, international collaborations in Croatian waters were rare in those years, as the procedure for obtaining permits in the former Yugoslavia was quite difficult. The port of Aenona continues to yield a great amount of interesting finds, including the remains of three sewn boats approximately dated to the first century BC (Brusić \& Domijan, 1985; Gluščević, 2004a). The first two vessels were raised but the conservation and presentation process was never completed, while the remains of the third one are still the object of the underwater research.

1967 was particularly fruitful in the Zadar region, as another important discovery took place near the islet of Gnalic, south of Biograd. Local divers indicated the position of a well-preserved shipwreck from the end of the sixteenth century. The wreck was partially explored in the following years (Petricioli, 1981; Radulić, 1970). Over the course of five excavation campaigns (1967-1968 and 1972-1973), eight guns, two big anchors, and numerous objects belonging to the ship's equipment and cargo were raised from the seabed, although only a small portion of the shipwreck was actually researched. Thanks to the complex conservation process organized in Zadar and abroad (Petricioli, 1981: 39-44), the material was exhibited in the newly established Municipal Museum of Biograd. The site, therefore, was never fully protected on the seabed, and its long-term looting continues even today.

Although the Gnalic wreck has proven to be one of the most interesting examples of a post-medieval trading vessel of probable Venetian origin with well-preserved hull remains, its research was never organized as a systematic project. The task was apparently too complicated for the system that for several following decades put the accent on rescue excavations, undertaken mostly on sites from the Roman period. Recent attempts to realize the systematic research at the international level are promising the completion of the project.

Stimulated in great part by the discovery of the Gnalic wreck, the first initiative for organized work came from the Institute of Archaeology at the University of Zagreb. Its director, Mate Suic, proposed the establishment of a centre for maritime archaeology and a specialized museum for underwater archaeological finds (Vrsalović, 1974: 28). In 1968, the Republic Institute for the Protection of Cultural Monuments, directed by Vlado Mađarić, organized the first informative meeting on this subject in Zagreb, and in 1969 began to coordinate the protection of underwater cultural heritage. The role of coordinator was assigned to archaeologist Dasen Vrsalović. Thanks to his passionate work, maritime archaeology in Croatia made great progress in the following decade. The first meeting of representatives from coastal museums, regional institutes for the protection of cultural monuments, the navy and diving organizations was held in Sibenik the same year with the aim of proposing a model for future work (Vrsalović, 1974: 30-31). The Commission for Underwater Archaeological Activities was established in order to propose projects, define priorities, and supervise underwater 
archaeological excavations and surveys. Another important step was the creation of so-called Action Groups in Pula, Rijeka, Zadar, Šibenik, Split, and Dubrovnik, with each group composed of an archaeologist interested in the field and local divers. Efforts to include representatives from the navy, police, harbour authorities, and other organizations responsible for the protection of the sea were never fully realized.

Worthy of mention is one of the decisions reached in 1973 at the meeting in Šibenik regarding in situ preservation of submerged archaeological sites. In effect, in situ preservation was to be given precedence over other methods of protection in cases of difficult and fragile underwater archaeological sites. In time, this became a common practice in Croatian waters, and it has fallen in line with the 2001 UNESCO Convention on the Protection of Underwater Cultural Heritage.

The meeting also pointed out the necessity of organizing a well-structured network of collaborators that would act as 'guardians' of underwater archaeological sites. These guardians would receive certain responsibilities, but would also earn awards. Although extremely difficult to organize and enforce, this system presents probably the only way to protect Croatia's complex maritime area.

One curious lacuna in the meeting, and in the subsequent development of policy and administration, is the inclusion of inland waters; the focus has been exclusively on the Adriatic coast. The finds, often made by chance, began to attract the interest of archaeologists only towards the end of the last century, and even today exploitation of inland waters represents a scarcely researched area (Milošević, 1999; Radić Rossi, 2009b; Radman Livaja \& Zubčić, 2009).

It is not an easy task to express in short all the interests and achievements of
Dasen Vrsalović. His extremely active work, unexpectedly interrupted after ten years, stimulated a great development in maritime archaeology in Croatia and established solid foundations for all future work. Vrsalović took an intense interest in nearly all its facets, such as proposing programs and projects; coordinating the work of the previously mentioned Commission; collecting field reports in one central place; organizing the professional meetings on an annual basis; educating students and enthusiasts; documenting finds from museums, monasteries, and private collections; interpreting the results of underwater surveys and excavations; mapping underwater sites; publishing underwater finds; and more. His book published in 1974 on exploring and protecting underwater archaeological sites in Croatia (Vrsalović, 1974), and his $\mathrm{PhD}$ thesis on commercial navigation routes and economic conditions in the Adriatic in classical antiquity (Vrsalović, 1979), continue to be the main source of information on the topic.

Working meetings in the form of symposia continued until 1975, when the first inter-republic meeting took place in Split, involving not just participants from Croatia but also those other Yugoslav republics facing the Adriatic Sea: Bosnia and Herzegovina, Montenegro and Slovenia. From the numerous reports on the symposia in publications of the Republic Institute for the Protection of Cultural Monuments, we can conclude that the academic discussions held at the time defined all the problems that are still present after more than 30 years systematic research, scientific approach, material storage, conservation, public presentation, active protection, cooperation, terminology, and definitions. Many interesting opinions were expressed and good solutions proposed. The last discussion on the results and problems of underwater 
cultural heritage to take the form of a symposium was the meeting held in Zadar in 1980. After that event, scientific discussion was left to the initiative of a restricted number of experts, whereas all the organized work concentrated mainly on site protection.

In 1976, a group of Croatian archaeologists participated in the Fifth International Congress on Underwater Archaeology, held on the Aeolian islands (Parker, 1976). Dasen Vrsalović, Radmila Matejčić, Nenad Cambi, Marijan Orlić, Zdenko Brusić, and Ivo Petricioli presented the current state of underwater archaeology in the Republic of Croatia. Their discussions raised the interest of the international community, which was impressed by the level of techniques, methodology, and documentation achieved in Yugoslavia in so short a time in comparison with other Mediterranean states which began their work much earlier (Vrsalović, 1979: 9798). The organization of the next meeting and membership of the international committee Forma Maris Antiqui were offered to Croatian experts. However, owing to the death of Nino Lamboglia, the main promoter of the congress and committee, those plans were never fulfilled. The next opportunity for a comprehensive international meeting on the subject to be organized in Croatia happened just three and a half decades later with the organization of the IKUWA 4 (International Conference of Underwater Archaeology) in Zadar at the end of September 2011.

In terms of organized and systematic work on discovering and studying underwater sites, the 1970s were the most productive years. More than 200 sites were registered, and a number of rescue excavations were organized in order to explore and protect important shipwrecks and sunken ports. Numerous so-called 'scattered sites', consisting of materials that could not be defined as the cargo of a sunken ship or the remains of a submerged port or other coastal structure, as well as single finds, were also registered with great care.

The largest excavation of a Roman shipwreck took place in the bay of Vela Svitnja on the island of Vis, where the well-preserved remains of a merchantman with a cargo of Lamboglia 2 amphorae was discovered. More than 600 amphorae were raised from the seabed over the course of three excavation campaigns (Cambi, 1989: 311-15; Vrsalović, 1979: 225-28). The storage of the amphorae presented another problem that was resolved some 20 years later, when the surviving finds were exhibited in the store areas of the old fortress in Vis (Figure 4). The site of Vela Svitnja has yielded the largest cargo of amphorae raised to date from the Croatian seabed.

Amphorae of Lamboglia 2 types were discovered on a great number of sites, representing the most common finds in the Croatian waters and testifying to their origin from the Adriatic area. After the site of Vela Svitnja, one of the most interesting excavated sites with a cargo of Lamboglia 2 amphorae was discovered in the bay of Stari Stani in the Pakleni Islands, where a ship sank in the upright position on a plain sandy seabed (Orlić \& Jurišić, 1989; Parker, 1992: 412-13).

In 1972-1974 a post-medieval shipwreck in front of the bay of Suđurad on the island of Šipan near Dubrovnik (Ragusa) was partially explored (Kisić, 2006). Much later, documents recovered in the State Archive in Dubrovnik revealed that the sunken ship can be identified as a nava named Sv. Jerolim (S. Girolamo). The ship, which belonged to Jere Primoevic, a rich Ragusan merchant, sank in 1576 (Vekarić, 1987). It is interesting to note that the documents refer to salvage operations conducted by Greek divers at the beginning of the seventeenth century in order to raise 


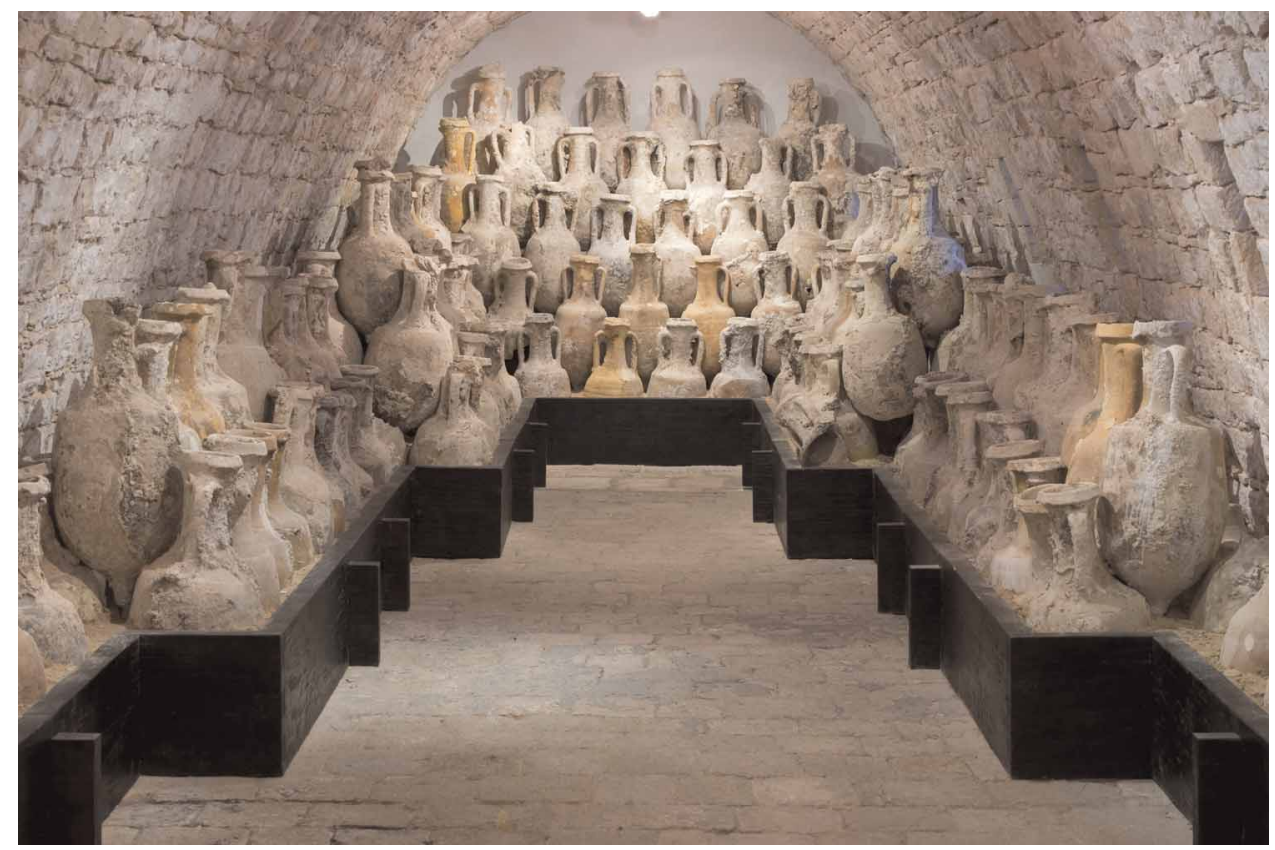

Figure 4. Wine amphorae Lamboglia 2 from the shipwreck of Vela Svitnja, displayed in the Issa archaeological collection in Vis.

Photo: R. Mosković.

the guns and other valuable objects from the sea. The wooden hull remains remained on the seabed covered by sand, as there was no possibility to explore them in detail. In situ preservation in this case may prove unsuccessful, as there are signs of aggressive action on the part of Teredo navalis. The same problem has recently been noticed at other documented and partly explored post-medieval shipwrecks. The importance of the maritime Republic of Dubrovnik (Ragusa) in the Croatian history of navigation places this shipwreck among the most important sites to be explored in the future.

Of Roman-period wrecks, it is difficult to list all the discoveries and rescue excavations undertaken during the 1970s and 1980s. Among the most important we should mention the Early Imperial shipwreck near the island of Ilovik (Jurišić, 2000: 65; Orlić, 1986; Parker, 1992: 215), with flat-bottomed amphorae of the so-called Forlimpopoli type and luxury bronze and glass vessels. It was found intact in the mid-1960s, but was heavily looted until excavation was organized nearly twenty years later.

Near the promontory of Plavac on the island of Zlarin, various interesting finds from the first century AD were registered, and some frames and planks of significant dimensions were recovered, permitting an estimate of the length of the ship at $30 \mathrm{~m}$ (Brusić, 1974: 103; Jurišić, 2000: 71; Parker, 1992: 318; Vrsalović, 1979: 19398). Although the rescue excavations continued for five campaigns (1972-1977), the shipwreck was only partly rescued and the material never published in detail.

The most significant shipwreck from the third to fourth centuries was explored in the bay of Sobra on the island of Mljet (Kisić, 1987; Parker, 1992: 408). Although looted and partly destroyed by 
the sinking of an Italian armed fishing boat that sank during the World War II, the site was notable for its evolution from a standard excavation to a rescue recovery due to the project's financial difficulties. The 20-25 m long ship was transporting an estimated total of 1000 vessels, including North African cylindrical amphorae, Almagro 50 and a variety of flat-based amphorae and jars. However, only 51 complete examples were recovered.

Thanks to the coordination from the central office in Zagreb, and the efforts of the regional centres along the whole coastline, underwater archaeological work in Croatia made great progress and produced significant results. For these reasons, it was unfortunate that the system was not allowed to improve, but ended in the dissolution of both the Action Groups and the Commission for Underwater Archaeological Activities.

\section{Development of Maritime Archaeology in Croatia Over the Past Two Decades}

Over the past two decades, most of the work in Croatian waters has continued with more or less the same intensity, waning only during the Croatian Homeland War (1991-1995). During the creation of the present state of Croatia, the Department of Archaeology of the Republic Institute for the Protection of Cultural Monuments in Zagreb became part of the Ministry of Culture and was transferred in 2004 to the Croatian Conservation Institute. Another department of underwater archaeology was formed in the Archaeological Museum in Zadar, while the University of Zadar for some years introduced a postgraduate underwater archaeology programme. The coordination experienced in the 1970s lost its effectiveness, and, as a result of the transfer of the Department in Zagreb from the Ministry of Culture to the Croatian Conservation Institute, all administrative decisions regarding underwater cultural heritage were left to regional conservation offices. With this act, the idea of a documentation centre for all underwater archaeological research was abandoned and the systematic mapping of all underwater finds, including scattered sites and chance finds, became much more difficult.

The discovery of new finds, however, did not abate. From 1989 to 1991, the excavation of one of the most interesting Roman shipwrecks took place near Cape Glavat on the island of Mljet. The late first to early second century AD wreck was transporting a cargo not only of amphorae and pottery but also of raw glass, lead minerals, and semi-finished products to be used in the production of pigments and pure lead (Jurišić, 2000: 61-63; Radić Rossi, 2009a) (Figure 5). According to analyses undertaken at the Stazione Sperimentale del Vetro on Murano (Venice), the provenance of the raw glass appears to have been the Syro-Palestine region, while the lead minerals and unworked products probably originated in the Dalmatian hinterland. A number of ceramic vessels, oil lamps, and other objects belonging to the

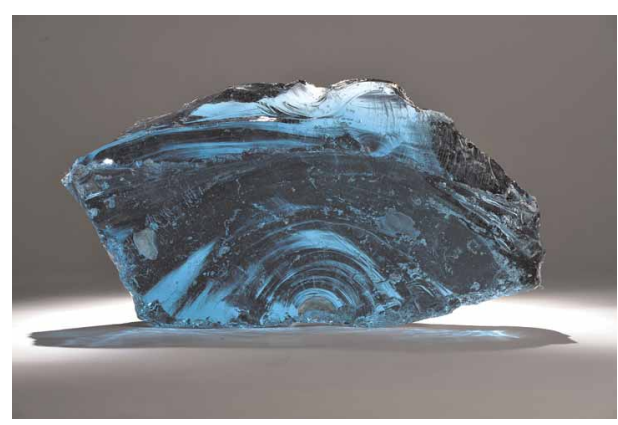

Figure 5. Chunk of raw glass from the shipwreck of Cape Glavat on the island of Mljet.

Photo: D. Kalogjera. 
crew and ship's equipment were also found, but in this case, as in many others, the rescue character of the excavation prevented the formulation of a complete analysis of the site.

In 1994-1995, a third to fifth century $\mathrm{AD}$ shipwreck was excavated in the Bay of Duboka on the island of Hvar. A cargo of Africana II A-C, Keay XXV and Aegean amphorae was brought to light, together with a remarkable quantity of cow, chicken, and pig bones (Jurišić, 2006b: 189), while the significantly preserved part of the hull was left unexplored on the seabed. The year 2000 saw the beginning of the systematic excavations on a firstcentury $\mathrm{AD}$ shipwreck at Grebeni, near Silba (Gluščević, 2004b), with its cargo of Dressel 2-4 amphorae and many finds belonging to the ship's equipment. The project is still in progress.

From 1996 to 1999, a group of sites was discovered offshore of Cavtat (the site of ancient Epidaurum) south of Dubrovnik. Near the islet of Supetar, three Roman shipwrecks were recorded: a looted shipwreck with a cargo of Lamboglia 2 amphorae, a well-preserved shipwreck with a cargo of an estimated 1200 Africana II and Aegean ovoid amphorae of the third to fourth centuries $\mathrm{AD}$, and an isolated group of at least eight dolia (Figure 6) (Jurišić, 2000: 73, 2006a: 187). Not far away, a well-preserved wreck from Napoleonic times was surveyed. It was carrying six iron cannons and various objects belonging to the ship's equipment, all of which were visible on the surface of the seabed. The accumulation of these sites in a relatively small area about thirteen years ago stimulated the idea of an underwater archaeological park, which has not been realized until today. Compared with the situation in neighbouring Italy, where the underwater parks like Baia Sommersa near Neaples, the underwater itineraries of

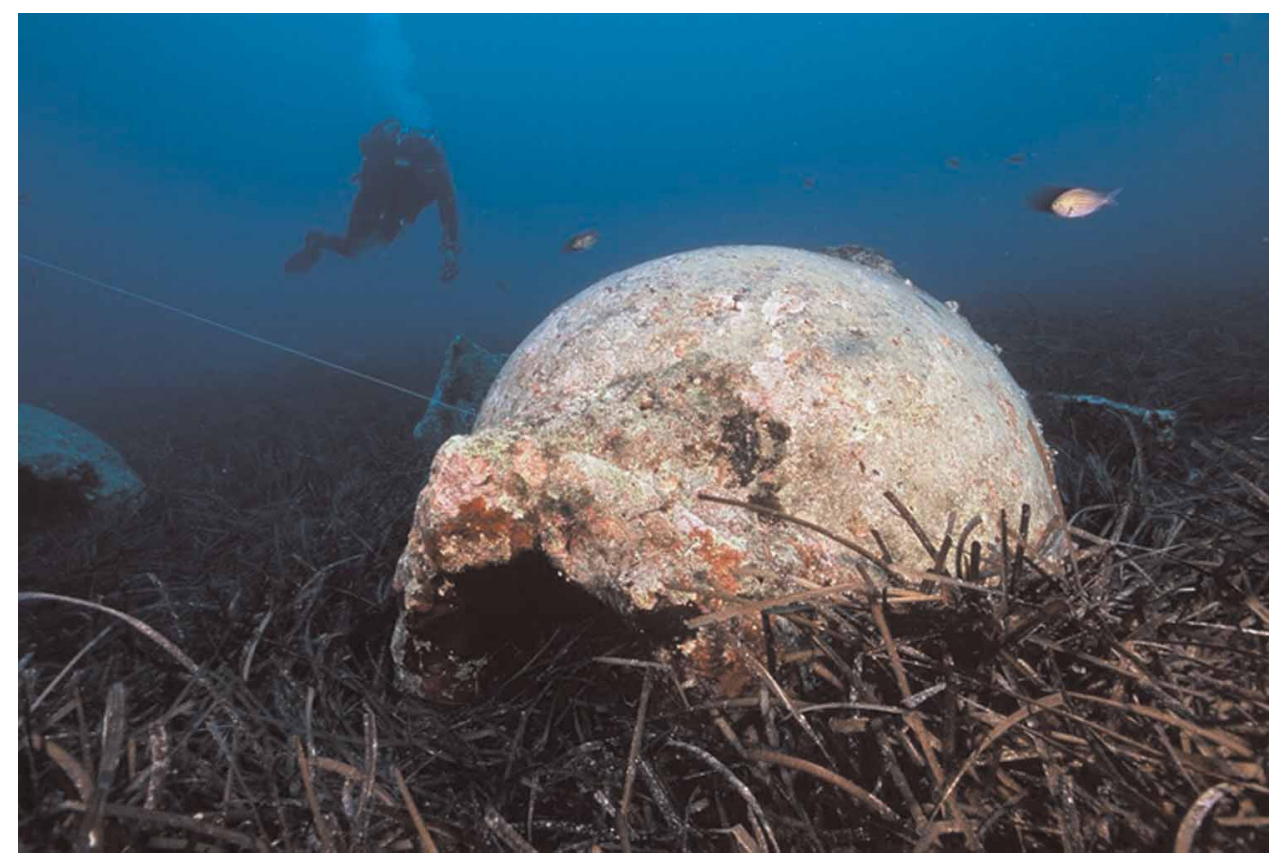

Figure 6. One of the entirely preserved dolia on the site of the islet of Supetar in front of Cavtat. Photo: D. Frka. 
Pantelleria or recently inaugurated Calarcheo of Reggio Calabria have become a functional reality, it is not entirely clear why such an idea never succeeded in Croatia. It seems that the insufficient cooperation between the local communities and the responsible institutions represents the main obstacle towards its realization.

In 1999, another important find generated great interest in underwater cultural heritage. The discovery of the Hellenistic bronze statue of a young athlete found near the islet of Vele Orjule off the island of Lošinj in the Northern Adriatic was the first and only discovery of such an important artistic monument in Croatian waters (Sténuit et al., 2001) (Figure 7). The cleaning and conservation process of the bronze statue took 7 years, at the end of which it went on exhibition in Zagreb and Florence (Domijan \& Karniš, 2006; Michelucci, 2006). The excavation of the discovery site brought to light its base which is decorated with meanders, but no traces of a shipwreck were found, nor did an extensive survey of the surrounding area produce any positive results. The lack of any other find directly associated with the statue prevents conclusions regarding its date or the circumstances of its position on the seafloor. There are some indications that suggest a connection with the first or second century $\mathrm{AD}$ shipwreck discovered near the island of Ilovik, mentioned above, but this has yet to be verified.

The early and energetic years of Croatian maritime archaeology saw the discovery of numerous coastal sites that have provided rich evidence for ports and settlements, mainly from the Roman period, but also from prehistoric, medieval and modern times. A salient example is provided in the Bay of Kaštela. The ancient city of Salona,

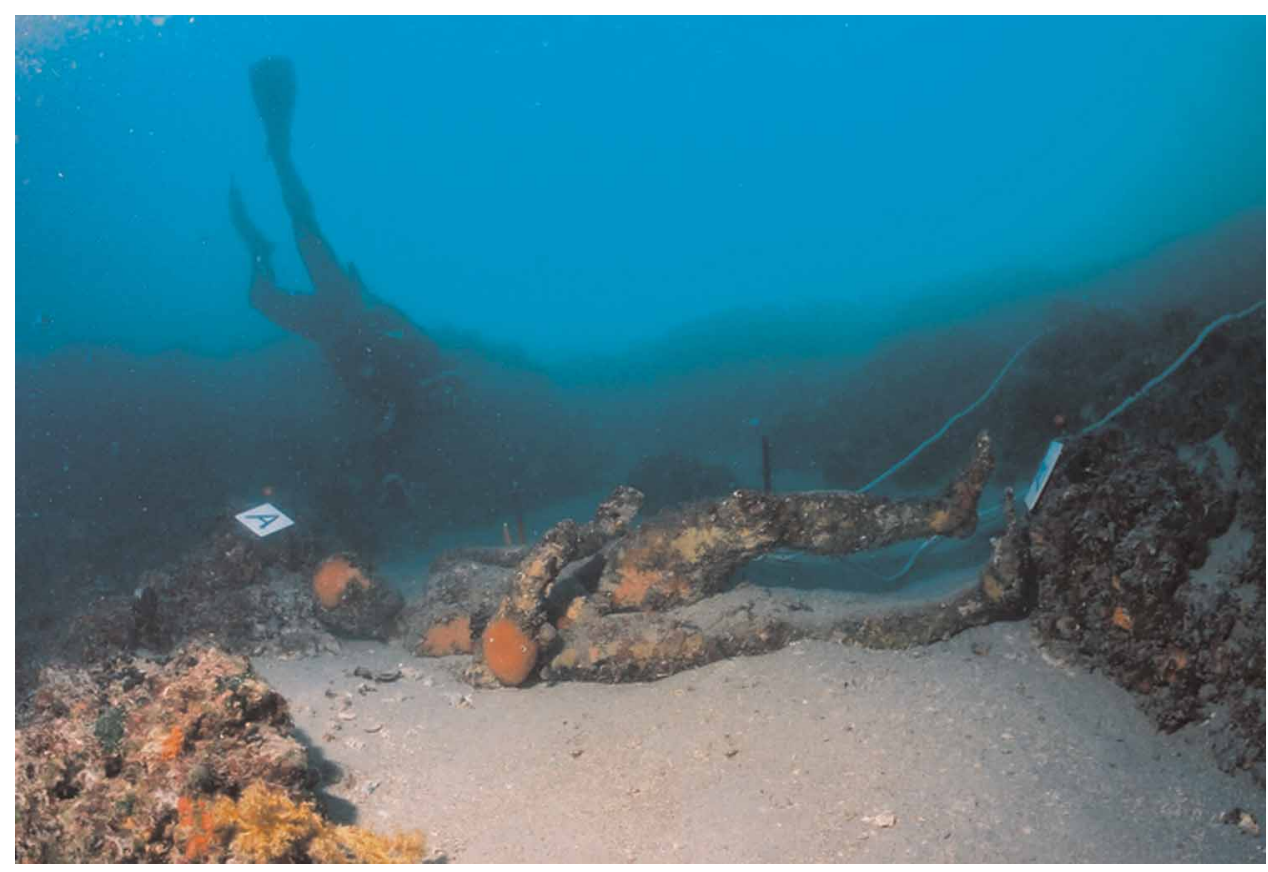

Figure 7. Bronze statue of a young athlete found off the island of Vele Orjule near the island of Losinj.

Photo: D. Frka. 
including its Portus Salonitanus and its ager Salonitanus, extended around the entire eastern end of the bay, while the other important Roman city of Tragurium lay at its western end. Coastal and maritime activity near both sites should have left visible traces in the shallow waters of the bay, but industrial development over the past century has suffocated the whole area, causing widespread destruction on land and polluting the bay to the point that diving activities have been reduced to a minimum.

The situation started to change in the late 1980s when local divers pointed out an interesting Hellenistic and Roman settlement in Resnik (Brusić, 1990), which later showed evidence of a submerged prehistoric settlement. Since then, at least 10 other sites have been discovered around the shores of the bay down to a depth of $5 \mathrm{~m}$. They consist primarily of wooden structures from the Roman period, built most likely for the commercial production of salt and perhaps fish. Many appear to have been reinforced with amphorae and even with purposely sunken boats.

Four sites in the bay of Kaštela yielded dolia whose surfaces were curiously perforated. Other fragments of perforated dolia have been found in the port of Vis on the homonymous island, the bay of Caska on the island of Pag, at Pakoštane near Biograd, and in the bay of Vela Luka on the island of Korčula. To date, these curious finds have been found at a total of eight sites, but are not attested elsewhere in the Mediterranean.

During underwater rescue excavations in Vranjic in 2005 and 2006, a $4.5 \mathrm{~m}$ high profile was exposed below sea level, preserving stratigraphy from the Bronze age to the Late Middle ages (Radić Rossi, 2008a, 2008b). Such sites have stimulated the study - among both Croatian and foreign scholars - of sea level changes and reconstructions of paleolandscapes (Fouache et al., 2006; Antonioli et al., 2007; Faivre, Bakran-Petricioli \& Horvatinčić, 2010; Faivre et al., 2011).

Among other interesting sites that have recently provided much information on sea level change from Eneolithic to Roman times is the site of Pakoštane. Known since the 1970s (Brusić, 1977), the site was 'rediscovered' in 2004 when a short-term excavation of a Roman port began with excellent results (Ilkic et al., 2008). In the same year, a Late Roman shipwreck in shallow waters was documented, and the work continued with survey and rescue excavation of wooden structures possibly belonging to Roman salt pans. As excavations reached exposed beach rock contemporary with the Neolithic period, and also the probable remains of a submerged Neolithic/Eneolithic settlement, the site has become one of the most important places where we can trace the evolution of submerged landscapes and sea levels over the past eight millennia.

The Late Roman shipwreck at Pakoštane has become a benchmark for the development of Croatian nautical archaeology within an international framework designed to promote this long-neglected field (Boetto et al., 2008) (Figure 8). The project on ships and seafaring in Roman Dalmatia, directed by the University of Zadar and CNRS - Centre Camille Jullian (Aix-en-Provence, France), continued in the bay of Caska at the island of Pag, where the remains of another indigenous sewn boat from the Roman period, similar to the finds from the bay of Zaton near Nin, were excavated and studied in detail. The extreme abundance of archaeological, paleobiological, geological, and geomorphological evidence extended the research to the comprehensive reconstruction of the paleolandscape and the interpretation of the broad context of the find. 


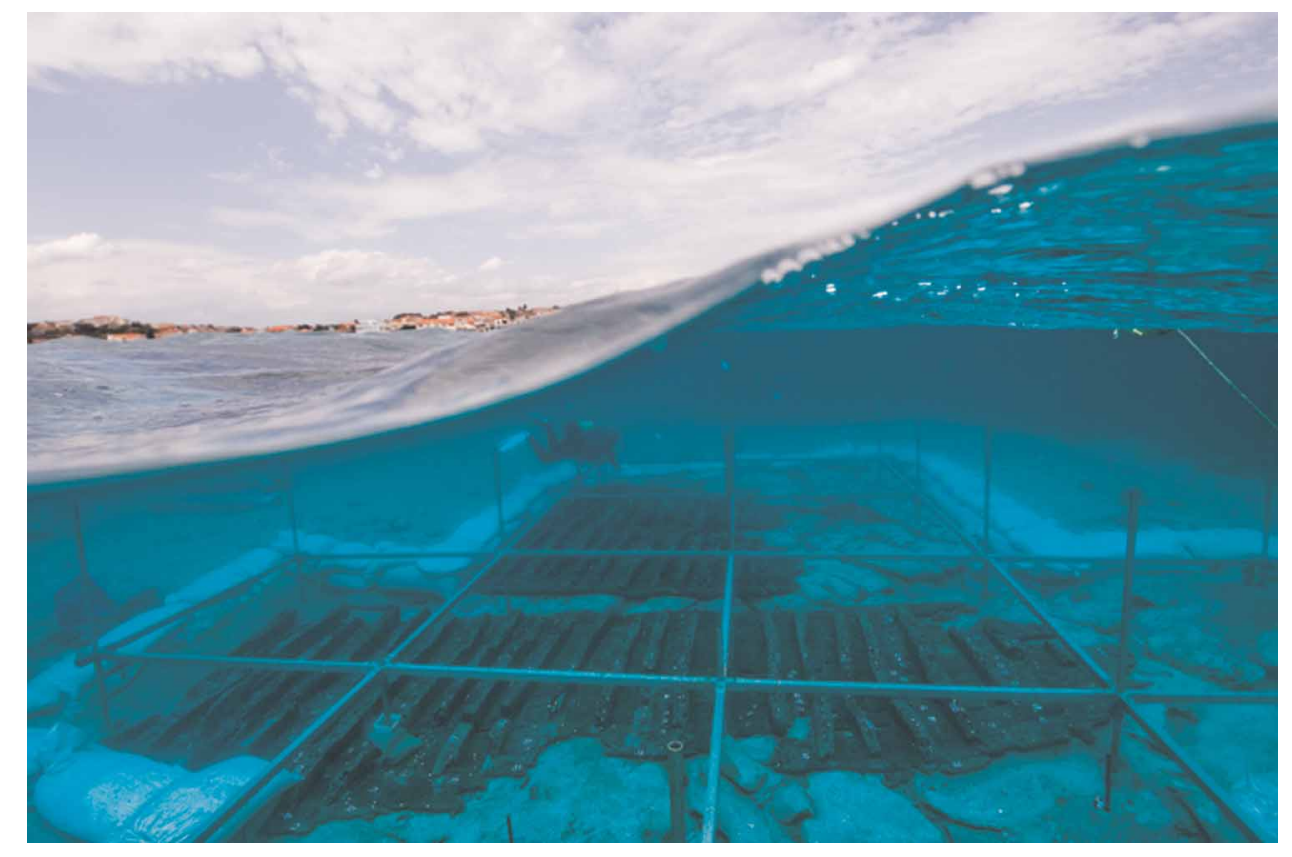

Figure 8. Late Roman shipwreck of Pakostane in the course of excavation; research campaign 2007.

Photo: Ph. Groscaux.

In 1994, an international scientific cooperation began in Istria, concentrating on coastal Roman commercial structures and ports (Tassaux et al., 2001). The international project, entitled 'Istria and the Sea', was first carried out by the Regional Museum in Poreč in cooperation with the Institut Ausonius of the University Bordeaux III (France) and, during the last decade also involved the Department of Antiquities of the Faculty of Philosophy of the University of Pisa (Italy), CNRS - Centre Camille Jullian (Aix-en-Provence, France), and École Française de Rome (Italy).

And recently, several international projects have addressed the delicate sites of post-medieval wrecks. Such international and interdisciplinary cooperation has proven to be very useful in terms of stimulating scientific research and more accurate underwater work.

The international research project on mapping the heritage at greater depths was launched in 2010 by the University of Zadar, the Faculty of Electrical Engineering and Computing of the University of Zagreb, and AURORA Ocean Exploration and Education Trust. Entitled TRITON - Deep Water Heritage Research Project, it represents the first attempt at systematic survey, aimed at detecting the cultural and natural heritage in the deep sea of the targeted area. In comparison to the other projects of its kind, its specific value consists in providing evidence for both cultural and natural heritage studies at the same time, making it possible to consider their interaction. It is worth emphasizing its educational aspect, as the transfer of knowledge in applying the new technologies on underwater research to the young Croatian researchers - provided by AURORA Trust - greatly contributes to the development of the local research potential. 
The idea of the TRITON project arose during the first 'Breaking the Surface' international field training programme, organized in the framework of the FP7 CURE project in Murter in 2009, and focused on applying underwater robotics to marine biology, underwater archaeology and maritime security.

Inspired by the early ratification of the 2001 UNESCO Convention on the Protection of the Underwater Cultural Heritage, the Ministry of Culture established in 2007 the International Centre for Underwater Archaeology in Zadar as part of the Croatian Conservation Institute, that in 2009 became an independent institution proclaimed as a UNESCO Category II Centre. The Centre became responsible for the educational activities in the field of exploration, conservation, and restoration of the underwater cultural heritage, as well as promotion and implementation of the UNESCO Convention in the region (International Centre for Underwater Archaeology in Zadar, 2012). This development represented a big step forward towards the efficient protection of the rich and heterogeneous underwater cultural heritage of Croatia, and training of the underwater researchers in Southeastern Europe.

A high level of underwater archaeological research has been recently achieved in Slovenia (Gaspari et al., 2006; Poglajen, 2008; Stokin et al., 2008), and several international projects are currently putting effort into stimulating the underwater archaeological activity in Montenegro and Albania (Royal, 2009; Volpe et al., 2008, 2010). Together with the long Croatian underwater research experience, this work will certainly help fill in the picture of Eastern Adriatic seafaring and trade through the ages and help to develop a common system for the long-term protection of underwater cultural heritage.

\section{Legislation}

The protection of underwater cultural heritage, as part of cultural heritage in general, is regulated by the 'Law on Protection and Preservation of Cultural Goods', issued in 1999 and integrated in 2003 (NN 66/99, 151/03 \& 157/03). Good legislation, partly inherited from the old system, is generally considered the main reason why Croatia was never affected by large-scale treasure hunting or international projects of doubtful benefit.

The 'Register of Cultural Goods of the Republic of Croatia', defined by the Law, represents the main tool for the efficient administration and protection of Croatia's tangible and intangible cultural heritage. The Register contains the exact geographical position of the site, a short description, and measures to be undertaken for its protection. It comes into force by being published in Narodne novine, the official journal of the Republic of Croatia, stating the name and the geographical coordinates of the protected area. Although publishing of the exact positions of the underwater sites has been seriously criticized, nothing has changed and the information remains publically available. As the geographical complexity of the Adriatic coastline represents the main obstacle to the constant monitoring of the important spots, such a situation facilitates the undesired clandestine actions.

All the archaeological surveys and excavations, either on land or underwater, are regulated by the 'Regulation on Archaeological Research’ (NN 102/10), which states the main rules for realizing the archaeological work. For the international scientific community, it is interesting to mention that any international project proposed in Croatian waters should be directed by a Croatian citizen who fulfils the requirements of the Regulation, but can involve domestic and foreign participants. This fact refers 
exclusively to the administrative organization of the project and does not affect its internal scientific structure. The permit for the foreign participants can be requested by the project director, confirming their possession of an archaeological educational background, experience in organizing archaeological research, at least 12 months of fieldwork experience, CMAS $3^{*}$ category or equivalent, diving insurance, and a medical certificate. The diving insurance and medical certificate are also required for all members of the diving team, whatever their professional status. Another requirement stated by the Regulation is the obligation to publish the results of the project first in Croatia and in the Croatian language.

In 2004, the Ministry of Culture launched the publication entitled Croatian Archaeological Yearbook, containing preliminary reports on all the land and underwater archaeological surveys and excavations undertaken in the current year. The timely publishing of the reports by the project directors is a requirement for the continued issuing of excavation permits.

All the permits for the underwater archaeological work, from basic survey to systematic excavation, are issued by the regional Conservation Offices of the Ministry of Culture: nine of them covering the coastline and hinterlands, another twelve the inlands of Croatia. The permits are issued for the current year and, if needed for fundraising, a year in advance. They define: the rights and obligations of the project director; the exact place, time and membership of the research team; methodologies and techniques to be applied and the deadline for the submission of the preliminary reports. Unless otherwise stated, the reports have to be submitted within a 3-month period from the end of the research campaign and should be accompanied by graphic and photographic documentation. The permits for the archaeological excavations can be issued only for the sites that are already inscribed in the previously mentioned Register of cultural goods of the Republic of Croatia or for those sites whose inscription is in the course of being realized.

According to the Regulation, the export of the archaeological finds is forbidden, except for analysis or conservation that cannot be undertaken in Croatia. A special export permit is also issued by the Conservation Offices of the Ministry of Culture, after the finds have been inscribed in the inventory of the museum appointed for their permanent deposition. The export of the original documentation is not allowed, while for the export of a copy a permit from the Conservation Office is also required.

In case of more complex international interdisciplinary scientific projects, the permit is issued by the Ministry of Science, Education and Sports, which assures the agreements of other ministries involved (Ministry of Culture; Ministry of Sea, Transport and Infrastructure; Ministry of Defence). Also in that case, the responsible Conservation Office of the Ministry of Culture issues the additional fieldwork permit.

It is worth mentioning the 'Regulation on the procedure and manner of issuance of permits to perform underwater activities in internal waters and territorial sea of the Republic of Croatia in the areas with the cultural goods' (Narodne novine 22/09 and $36 / 11$ ), which defines those underwater cultural heritage sites and zones of special cultural heritage interest where diving is not allowed unless organized by those diving centres that hold a five-year concession for their touristic exploitation. The sites and zones included in the concession are defined by the special program issued by the Minister of Culture every five years. This relatively recently established system has become a significant source of income for the cultural heritage protection service. 
The main criticism of this Regulation concerns the fact that the declarers of the sites are given no special benefit except being privileged in the process of assigning the concessions. Without being rewarded, having no further access to the sites, and having to pay a considerable amount of money for the concession, the divers are not encouraged to cooperate in discovering and protecting the underwater cultural heritage, and instead often try to keep the information secret.

\section{In situ Protection and Presentation of Underwater Cultural Heritage}

Over the last twenty years, a specific means of protecting Roman shipwrecks in situ was developed. The two Roman wrecks discovered at Lastovo in the late 1980s were prime candidates for in situ presentation. The lack of a museum on the island, the already full artefact stores of existing museums, complications caused by the need for desalinization of a large number of amphorae and the possibility of damaging them during removal of encrustations, were the main factors behind the proposal to leave the finds in their original place. At the same time the attractive aspect of the sites - at a depth accessible to sport divers and excellent visibility - supported the idea of presentation instead of a complete physical covering of the exposed objects (Jurišić, 2006b). When tampering was discovered with the initial wire mesh, both wrecks were fitted with more solid iron cages.

With the discovery of five other wellpreserved sites, the cages improved and became more and more practical (Figure 9). They were designed in

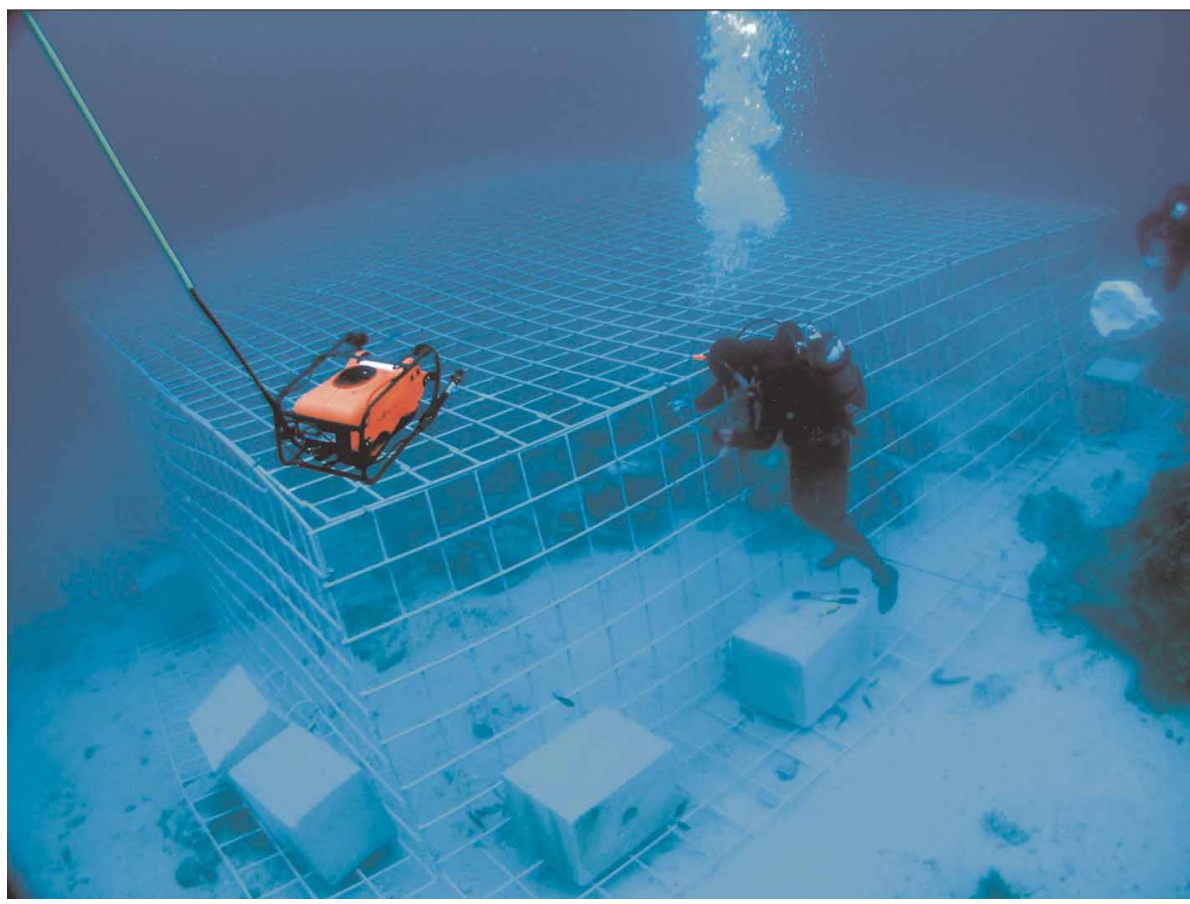

Figure 9. Protective cage placed over the first century BC shipwreck in the Vlaška Mala Cove on the island of Pag.

Photo: I. Radić Rossi. 
different ways to best correspond to the dimensions of the site and the morphology of the sea bottom. The opening at the top allows experts to enter the cage in order to check or document finds, while openings in the iron mesh covering the sides of the cages allow diving visitors to enjoy, examine, and photograph the sites. On a plaque mounted on the cage is etched basic information about the date of the wreck and its status as a protected monument in the National Register of Cultural Heritage Act. This serves as an additional psychological protection against looters, informing them that any damage they inflict is in direct violation of the law.

More than fifteen years of experience with iron cages has shown generally positive results in terms of keeping sites intact for eventual future research, whereas at the same time permitting the diving public to enjoy them. In contrast, despite the considerable investments in the new cage structures that are replacing those that collapsed, there are still significant problems.
Financial, ecological, aesthetic, maintenance and safety issues have never been tackled in detail. The required investments at the moment cannot be reasonably justified as there are no long-term management plans that also take into consideration the need for the constant attraction of visitors to all the physically protected Roman shipwrecks.

Another significant group of underwater cultural heritage sites to be studied, protected, and presented in situ consists of modern wrecks (Figure 10) and sunken aircraft, which in many cases represent important historical monuments connected to famous battles or other historical events (Frka \& Mesić, 2002). The great attractiveness of such sites to divers has demonstrated the necessity of protecting them by legislation and archaeological work, and to treat them as a most valuable cultural resource in need of close management. Many of these sites, however, lie at great depths and can be reached only by technical divers. This complicates proper

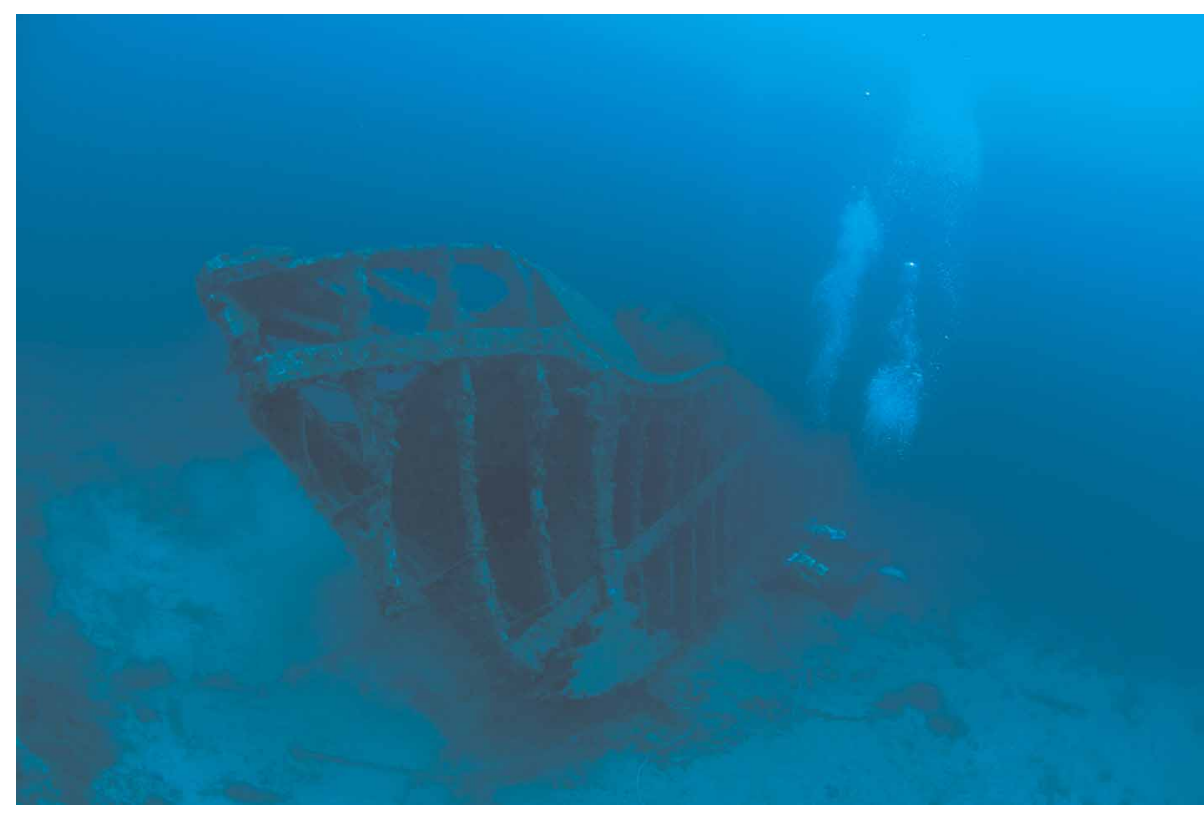

Figure 10. German S57 torpedo boat sunk off the Peljesac Peninsula.

Photo: D. Frka. 
site management efforts and raises the costs of all diving operations. In these cases, professional photographic and video documentation are crucial to presenting sites to the broader public and demonstrating their historical value.

Many sites dating to the nineteenth and twentieth centuries exist in Croatian waters. Some of them are well known and documented, whereas others remain to be explored or even discovered. The frequency of diving visitors, especially on sites that are freely accessible to the public, has compelled the state authorities to dedicate more and more attention to administrative side of underwater site protection.

Ancient wrecks protected with cages and modern wrecks and aircraft are sites worthy of cultural heritage management in the clear and generally calm waters of the Eastern Adriatic. However, in order to remain effective, that management requires well-structured projects that also involve local authorities, tourist organizations, and the diving community.

\section{Conclusion}

Efforts to protect Croatia's underwater cultural heritage have been ongoing for over 50 years. A wide variety of sites lie at a great range of depths, from shallow coastal waters to as deep as $100 \mathrm{~m}$ or more, and amphorae fragments pulled up from fishing nets working in depths of $400 \mathrm{~m}$ testify to the existence of Roman and Byzantine shipwrecks far from the coast. They serve as further evidence of open sea navigation in antiquity.

Despite indirect evidence from older periods and the well-attested presence of seafaring Liburnians and various Illyrian tribes on the Adriatic Sea, direct archaeological evidence of prehistoric navigation remains scarce in Croatian waters, although some recent deep water chance finds promise interesting discoveries. However, existing prehistoric evidence along the coast, including the recent discovery of the Late Bronze Age sewn boat in the bay of Zambratija in Northern Istria (Koncani Uhač, 2009), has stimulated research on prehistoric landscapes and could contribute much to our knowledge of the maritime aspects of life of prehistoric populations of the Eastern Adriatic.

The geographical qualities of the Croatian coast are from many points of view favourable to safe navigation, as noted by Strabo (VII, 5, 10), although in Classical Athens seafaring in the Adriatic was considered synonymous with extremely difficult and unsafe navigation (Athenaeus XIII, 612). It was only with the complete pacification of the province of Dalmatia in the first century AD that Rome established safe short- and long-distance trading routes in the region, as it did throughout the Mediterranean. The abundance of evidence from the Roman period continues to provide a great quantity of data for detailed studies on the seafaring and maritime economy of the time.

During the turbulent period of the Great Migration, after Justinian's Reconquista, the Eastern Adriatic navigation route was controlled by a series of fortifications built among the islands and along the mainland coast. After the arrival of Slavs and specifically Croats in the seventh century $\mathrm{AD}$, the main cities continued to affirm the sovereignty of the Byzantine emperor, and the process of slow assimilation of Roman and Slavic populations continued into the Middle Ages. The continuous efforts by different states to control the Eastern Adriatic coast resulted in a permanent flux of political and seafaring conditions, culminating in the rise of the Republic of Dubrovnik, a great rival of Venice, in the fifteenth and sixteenth 
centuries. The main characteristics of maritime economy, navigation and trade in different periods influenced the composition of the underwater evidence. The best examples are the round ships that from the mid-sixteenth century, transported great quantities of goods. Many of these ships have left abundant traces on the seabed.

Although the majority of the underwater sites belong to classical antiquity, underwater archaeological research in Croatia from the very beginning of its modern history paid more attention to post-mediaeval shipwrecks than many other Mediterranean countries.

Over the past two decades, interest in modern shipwrecks and sunken aircraft has developed rapidly. They comprise a completely different kind of underwater evidence, mostly connected to great battles and wars, and therefore of much more symbolic historical value. They have become the main targets of divers and, therefore, together with some Roman shipwrecks protected in situ, stimulated the first steps in the management of underwater cultural heritage in terms of sustainable development. Although much work remains to be done, the current results demonstrate that underwater archaeological and historical sites show great potential for special forms of cultural tourism and for raising awareness of the importance of their preservation. The recent establishing of the International Centre for Underwater Archaeology in Zadar will surely contribute substantially to this field.

Despite the intensity of underwater research in Croatia and the high quality of underwater excavation methods, there are also some weak points worth pointing out. Maritime archaeology in Croatia, apart from the energetic period of the 1970s, reflects more a series of isolated actions than organized and systematic work that undertakes equal effort in the protection, management, and scientific study of underwater cultural heritage. At present, priorities are dependant more on the personal interests and aspirations of the experts involved than on an accurate evaluation of all points of view. The insistence on the protective (i.e. rescue) character of underwater excavations limits the scientific approach to a great extent, whereas the intensity of protective work allows no room for the development of specialization among the insufficient number of experts in the field. Paradoxically, regardless of all the energy expended on protection, some important coastal sites continue to pay a high price to development, without even being explored.

The lack of a university program aimed at fostering specialists in maritime archaeology has constrained the level of scientific research and has failed to attract the next generation in the study of underwater cultural heritage. The very restricted courses are totally insufficient when balanced against the demands of the situation: there is an urgent need to concentrate efforts at establishing a more complex maritime archaeology academic programme. The first steps in that direction have been recently undertaken at the University of Zadar.

In the words of Fernand Braudel, "The Adriatic is perhaps the most unified of all the regions of the sea. It provides material for all the problems implied in a study of the Mediterranean as a whole' (Braudel, 1984: 125). Braudel's vision may be fulfilled if future work in Croatia follows the idea of interdisciplinary and integrated studies of its rich underwater cultural heritage.

\section{ACKNOWLEDGEMENTS}

The author thanks Professor Zdenko Brusic of the University of Zadar and 
Dalibor Martinovic of the Municipal Museum of Šibenik for providing information on the history of Croatian underwater archaeology, and Dan Davis of the University of Texas at Austin for his editorial assistance.

\section{REFERENCES}

Antonioli, F., Anzidei, M., Lambeck, K., Auriemma, R., Gaddi, D., Furlani, S., Orrù, P., Solinas, E., Gaspari, A., Karinja, S., Kovačić, V. \& Surace, L. 2007. Sea-level Change During the Holocene in Sardinia and in the Northeastern Adriatic (Central Mediterranean Sea) from Archaeological and Geomorphological dana. Quaternary Science Reviews, 26: 2463-86.

Boetto, G., Marlier, S. \& Radić Rossi, I. 2008. The Pakoštane Shipwreck (Croatia): A Preliminary Report. In: I. Radić Rossi, A. Gaspari \& A. Pydyn, eds. Proceedings of the 13th Annual Meeting of the European Association of Archaeologists, Zadar, Croatia, 18-23 September 2007. Zagreb: Hrvatsko Arheološko Društvo, pp. 222-34.

Braudel, F. 1984. The Mediterrranean and the Mediterranean World in the Age of Philip II. vol. 1. London: University of California Press.

Brusić, Z. 1969. Podmorska arheološka istraživanja starohrvatskih brodova na ulazu u ninsku luku. Radovi Instituta JAZU u Zadru, 16-17: 443-48.

Brusić, Z. 1974. Rt Plavac, Zlarin kod Šibenika - ostaci antičkog brodoloma. Arheološki Pregled, 16: 103-4.

Brusić, Z. 1977. Prethistorijski podmorski nalazi na području južne Liburnije. Radovi Centra JAZU u Zadru, 24: 53-60.

Brusić, Z. 1978. Rezultati najnovijih istraživanja i vađenje starohrvatskih brodova na ulazu u ninsku luku. Adriatica Maritima, 2: 5-14.

Brusić, Z. 1990. Resnik kod Kaštel Novog. Arheološki Pregled, 29: 89-90.

Brusić, Z. \& Domijan, M. 1985. Liburnian Boats - Their Construction and Form. In: S. McGrail \& E. Kentley, eds. Serwn Plank Boats: Archaeological and Ethnological Papers Based on Those Presented to a
Conference at Greenwich in November 1984. Oxford: British Archaeological Reports, International Series 276, pp. 67-86.

Bulić, F. 1899. Tre sarcofaghi romani nel villaggio di Vranjic (Urania) sotto il livello del mare. Bulletino di Archeologia e Storia Dalmata, 22: 105-11.

Bulić, F. 1900. Ritrovamenti risgurardanti i sarcofaghi romani sotto il livello del mare nel villaggio di Vranjic presso Salona. Bulletino di Archeologia e Storia Dalmata, 23: 141-42.

Cambi, N. 1989. Anfore Romane in Dalmazia. In: Anfore Romane e Storia Economica: Un Decennio di Ricerche. Atti del Colloquio di Siena, 1986. Roma: École Française de Rome, pp. 311-37.

Coppo, P. 1540. Piero Coppo del sito de L'Istria (A Iosepho Favstino). Venezia: Francesco Bindoni \& Mapheo Pasini.

Degrassi, A. 1955. I porti romani dell'Istria. In: Anthemon. Scritti di Archeologia e di Antichità Classiche in Onore di Carlo Anti. Firenze: G. C. Sansoni, pp. 119-69.

Domijan, M. \& Karniš, I. eds. 2006. Hrvatski Apoksiomen/The Croatian Apoxyomenos: Katalog Izložbe/Catalogue of the Exhibition. Zagreb: Ministarstvo Kulture RH.

Donati, V. 1750. Della Storia Naturale Marina dell'Adriatico. Venezia: T. \& G. Edizioni.

Fortis, A. 1774. Viaggio in Dalmazia. Venezia: Marsilio Editori.

Fouache, E., Faivre, S., Gluščević, S., Kovačić, V., Tassaux, F. \& Dufaure, J. 2006. Evolution on the Croatian Shore Line between Poreč and Split Over the Past 2000 Years. Archaeologia Maritima Mediterranea - An International Journal on Underwater Archaeology, 2: 115-34.

Faivre, S., Bakran-Petricioli, T. \& Horvatinčić, N. 2010. Relative Sea-Level Change During the Late Holocene on the Island of Vis (Croatia) - Issa Harbour Archaeological Site. Geodinamica Acta, 23(5-6): 209-23.

Faivre, S., Fouache, E., Ghilardi, M., Antonioli, F., Furlani, S. \& Kovačić, V. 2011. Relative Sea Level Change in Western Istria (Croatia) During the Last Millennium. Quaternary International, 232 (1-2): 132-43.

Frka, D. \& Mesić, J. 2002. Tajne Jadrana. Ronilački vodǐc po olupinama brvatskog Jadrana. Rijeka: Adamić.

Gaspari, A., Karinja, S., Erič, M., Poglajen, S. \& Čerče, P. 2006. Rimski pristaniški 
objekt $\mathrm{z}$ ribogojnico $\mathrm{v}$ Fizinah pri Portorožu: poročilo o raziskavah podmorskega najdišča v letih 2004 in 2005. Annales, 16: 421-42.

Gluščević, S. 2004a. Hydroarchaeological Excavations and the Discovery of the Third Sewn Liburnian Ship - Seriliae in the Roman Harbor of Zaton near Zadar. Archaeologia Maritima Mediterranea, 1: 41-52.

Gluščević, S. 2004b. Antǐcki Brodolom na Grebenima kod Otoka Silbe, Katalog Izložbe. Zadar: Arheološki Muzej Zadar.

Ilkić, M., Parica, M. \& Meštrov, M. 2008. Ancient Port Complex in Pakoštane near Zadar. In: I. Radić Rossi, A. Gaspari \& A. Pydyn, eds. Proceedings of the 13th Annual Meeting of the European Association of Archaeologists, Zadar, Croatia, 18-23 September 2007. Zagreb: Hrvatsko Arheološko Društvo, pp. 212-21.

International Centre for Underwater Archaeology in Zadar. 2012. International Centre for Underwater Archaeology in Zadar [online]. Zadar: International Centre for Underwater Archaeology in Zadar [accessed 6 March 2012]. Available at $\langle$ http://icua.hr/en>

Jurić, R., Oguić, S. \& Vilhar, B. 1994. Konzervacija i početak rekonstrukcije ranohrvatskih brodova iz Nina. Adrias Zbornik Zavoda za znanstveni i umjetnicki rad HAZU u Splitu, 4-5: 43-62.

Jurišić, M. 2000. Ancient Shipwrecks of the Adriatic: Maritime Transport during the First and Second Centuries AD. British Archaeological Reports International Series, 828. Oxford: Archaeopress.

Jurišić, M. 2006a. The Maritime Trade of the Roman Province. In: D. Davison, V. Gaffney \& E. Marin, eds. Dalmatia. Research in the Roman province 1970-2001. Papers in Honour of J.J. Wilkes. British Archaeological Reports International Series, 1576. Oxford: Archaeopress, 175-92.

Jurišić, M. 2006b. La protezione fisica dei siti archeologici sommersi del fondale marino nell'Adriatico croato. In: I. Radić Rossi, ed. Archeologia Subacquea in Croazia: Studi e Ricerche. Venezia: Marsilio, pp. 147-56.

Kisić, A. 1987. Nalaz potonulog trgovačkog broda s početka IV. Stoljéca u uvali Sobri na Mljetu. Anali Zavoda za Povijesne Znanosti IC JAZU u Dubrooniku, 24-25: 7-32.
Kisić, A. 2006. La nave ragusea del XVI secolo sul fondale marino della baia di Suđurađ sullisola di Šipan. In: I. Radić Rossi, ed. Archeologia Subacquea in Croazia: Studi e Ricerche. Venezia: Marsilio, pp. 127-45.

Koncani Uhač, I. 2009. Podvodna arheološka istraživanja u uvali Zambratija. Histria Antiqua, 17: 263-67.

Luetić, J. 1951. Moluntska iskapanja na II međunarodnom kongresu podmorske arheologije. Pomorstvo, 10: 285-87.

Michelucci, M. ed. 2006. Apoxyomenos: L'Atleta della Croazia/The Athlete of Croatia, Catalogo della Mostra. Firenze: Giunti Editore.

Mirnik, I. 1981. Mijat Sabljar u Solinu i Vranjicu god. 1854. Vjesnik za Arheologiju i Historiju Dalmatinsku, 75: 209-40.

Milošević, A. 1999. Archäologische Probeuntersuchungen im Flussbett der Cetina (Kroatien) zwischen 1990 und 1994. Archäologisches Korrespondenzblatt, 29(2): 203-10.

Nikolanci, M. 1961. L'archeologia sottomarina in Jugoslavia. In: Atti del II Congresso Internazionale di Archeologia Sottomarina Albenga 1958. Bordighera, pp. 23-26.

Orlić, M. 1986. Antĩ̌cki Brod kod Otoka Ilovika. Zagreb: Republički Zavod za Zaštitu Spomenika Kulture.

Orlić, M. \& Jurišić, M. 1989. Otok Sv. Klement / uvala Stori Stoni, Potonuli antički brod s teretom. Arheološki Pregled, 28: 89-90.

Parker, A.J. 1976. V International Congress of Underwater Archaeology. International Journal of Nautical Archaeology, 5(4): 347-48.

Parker, A.J. 1992. Ancient Shipwrecks of the Mediterranean and the Roman Provinces. British Archaeological Reports International Series, 580. Oxford: Archaeopress.

Petricioli, S. 1981. Deset godina rada na hidroarheološkom nalazu kod Gnalića. Godišnjak Zaštite Spomenika Kulture Hrvatske, 6-7: 37-45.

Petrić, N. 2006. Gli inizi dell'archeologia subacquea in Croazia: note storico archeologiche. In: I. Radić Rossi, ed. Archeologia Subacquea in Croazia: Studi e Ricerche. Venezia: Marsilio, pp. 13-22.

Poglajen, S. 2008. Comparison Between Using a Single Beam Echosounder and a Multi Beam Echosounder in 
Archaeological Fieldwork. In: I. Radić Rossi, A. Gaspari \& A. Pydyn, eds. Proceedings of the 13th Annual Meeting of the European Association of Archaeologists, Zadar, Croatia, 18-23 September 2007. Zagreb: Hrvatsko Arheološko Društvo, pp. 88-96.

Radić Rossi, I. 2008a. Rescue Excavations at Vranjic Near Split, Croatia. In: I. Radić Rossi, A. Gaspari \& A. Pydyn, eds. Proceedings of the 13th Annual Meeting of the European Association of Archaeologists, Zadar, Croatia, 18-23 September 2007. Zagreb: Hrvatsko Arheološko Društvo, pp. 151-66.

Radić Rossi, I. 2008b. Recenti scoperte sottomarine nella Baia di Kaštela. In: R. Auriemma \& S. Karinja, eds. Terre di Mare: L'Archeologia dei Paesaggi Costieri e le Variazioni Climatiche. Atti del Convegno Internazionale di Studi, Tieste, 8-10 Novembre 2007. Trieste \& Piran: Università degli Studi di Trieste \& Pomorski Muzej 'Sergej Mašera', pp. 285-98.

Radić Rossi, I. 2009a. Il vetro grezzo e le altre materie prime del relitto romano di Mljet (Meleda), Croazia. In: M. Buora \& I. Lazar, eds. Intorno all'Adriatico. Atti delle XIII Giornate Nazionali di Studio (Trieste - Piran/Pirano, 30-31 Maggio 2009). Quaderni Friulani di Archeologia, 19: 141-51.

Radić Rossi, I. 2009b. Dugouts of Croatia. In: R. Bockius, ed. Transfer and Exchange in Nautical Technology. Proceedings of the Eleventh International Symposium on Boat and Ship Archaeology, Mainz 2006. Mainz: Römisch-Germanischen Zentralmuseum, pp. 133-45.

Radman Livaja, I. \& Zubčić, K. 2009. L'archéologie fluviale en Croatie. Les Dossiers d'Archéologie, 331: 62-7.

Radulić, K. 1970. Brod kod Gnalića: naše najbogatije hidroarheološko nalazište. Vrulje, 1: 4-9.

Royal, J. 2009. Illyrian Coastal Exploration Program. The 2009 Campaign. INA Annual, Projects and Research, 2009: 45-54.

Steinbüchel, A. 1820. Dalmatien. Eine Reiseskizze. Jahrbücher der Literatur 12. Wien: C. Gerold.

Sténuit, M.-E., Sténuit, R., Orlić, M. \& Gluščević, S. 2001. A Preliminary Report on the Discovery and Recovery of a Bronze Apoxyomenos, off Vele Orjule,
Croatia. International Journal of Nautical Archaeology, 30(2): 196-210.

Stokin, M., Gaspari, A., Karinja, S. \& Erič, M. 2008. In: R. Auriemma \& S. Karinja, eds. Terre di Mare: L'Archeologia dei Paesaggi Costieri e le Variazioni Climatiche. Atti del Convegno Internazionale di Studi, Tieste, 810 Novembre 2007. Trieste \& Piran: Università degli Studi di Trieste \& Pomorski Muzej 'Sergej Mašera', pp. 56-74. Tassaux, F., Matijašić, R. \& Kovačić, V. eds. 2001. Lonon (Croatie): Un Grand Entre de Production d'Amphores à Huile Istriennes (1er-IVe s.p.C.). Bordeaux: Ausonius-Publications.

Vekarić, S. 1987. Dva najstarija primjera spašavanja broda u XVII i XVIII stoljeću u Dubrovniku. Adrias - Zbornik Zavoda za Znanstveni $i$ Umjetnicki rad HAZU u Splitu, 1: 65-71.

Volpe, G., Anastasi, A., Disantarosa, G., Leone, D., Mangialardi, N. \& Turchiano, M. 2008. Progetto Liburna: archeologia subacquea in Albania (I parte). Archeologo Subacqueo, 14(1-2) (41-42): 2-16.

Volpe, G., Anastasi, A., Disantarosa, G., Leone, D., Mangialardi, N. \& Turchiano, M. 2010. Progetto Liburna: archeologia subacquea in Albania (II parte). Archeologo Subacqueo, 14(2) (47): 5-10.

Vrsalović, D. 1974. Istraživanja i Zaštita Podmorskib Arheoloskib Spomenika u SR Hrvatskoj. Zagreb: Republički Zavod za Zaštitu Spomenika Kulture.

Vrsalović, D. 1979. Arheološka Istraživanja u Podmorju Istočnog Jadrana. Doctoral thesis. Zagreb: Sveučilište u Zagrebu - Republički Zavod za Zaštitu Spomenika Kulture.

\section{Biographical Note}

Irena Radić Rossi has been involved in the exploration and protection of the underwater cultural heritage in Croatia within the Department of Underwater Archaeology of the Republic Institute for the Protection of Cultural Heritage, the Ministry of Culture of the Republic of Croatian, the Croatian Conservation Institute, and, presently, the Department of Archaeology of the University of Zadar, where she is in-charge of 
maritime archaeology. She is actively engaged in the research, protection, and preservation of underwater archaeological sites and finds, as well as in the promotion of Croatia's underwater cultural heritage. Her main area of interest is seafaring and maritime trade in the Eastern Adriatic, i.e. ancient shipwrecks and submerged ports. She has led a number of underwater excavations along the Croatian coast, including of prehistoric to modern sites, and has organized the in situ protection of several well-preserved Roman shipwrecks.

Address: Department of Archaeology, University of Zadar, Obala kralja Petra Krešimira IV. 2, 23000 Zadar, Croatia. [email: irradic@unizd.hr]

\section{Podvodna kulturna baština i pomorska arheologija u Hrvatskoj: Pregled}

Arheološka nalazišta u plitkome moru dǔ hrvatske obale spominju se u literaturi od 16. st., a od 18. st. koriste se kao potvrda poniranja istočne jadranske obale. Krajem istoga stoljéca proi se puta spominje i jedan antï̌ki brodolom. Lovci na spužve i koralje zapǒceli su krajem 19. st. vađenje arheoloških nalaza iz hrvatskog podmorja napunivši brojne privatne i samostanske zbirke. Izolirane akcije zaštite podmorske kulturno-povijesne baštine provode se od polovice prošloga stoljéca, a od 1970. one postaju dio dobro organiziranog sustava. Iako se zapaža nedostatak sustavnog rada, niz rekognosciranja $i$ zaštitnih istraživanja obogatio je spoznaje o pomorstvu dǔ hrvatske obale i doprinijeo proǔcavanju morskog okoliša tijekom proteklib vremena. Nekoliko dobro očuvanih nalazišta iz antĩ̌kog $i$ novovjekovnog doba predstavlja odlǐcan potencijal za prezetaciju brvatske podvodne kulturno-povijesne baštine na mjestu nalaza.

Ključne riječi: podvodna arheologija, arheologija pomorstva, brodolomi, plovidba, kulturna baština, zaštita, očuvanje, Hrvatska

\section{Patrimoine culturel subaquatique et archéologie maritime en Croatie: un aperçu}

Depuis le $16^{e}$ siècle, les sites archéologiques des eaux peu profondes de la Croatie sont mentionnés dans des sources écrites, et servent depuis le $18^{e}$ siècle comme preuves de l'enfoncement de la côte adriatique orientale. C'est à la fin de ce même siècle que fût signalee la première épave romaine dans des eaux croates. Des plongeurs d'eponges et collectionneurs de corail rapportaient des trouvailles archéologiques des fonds au large de la côte croate, et contribuaient ainsi à la création de nombreuses collections privées et monastiques. C'est dans les années 1950 que débutaient des campagnes isolees pour la protection du patrimoine culturel subaquatique, et à partir de 1970 ces efforts intégraient un système bien organisé. Bien qu'il y ait toujours un manque notable de recherches systématiques, quelques études et fouilles de sauvetage ont enrichi nos connaissances de la navigation ancienne le long des côtes croates et ont contribue à l'etude de l'environnement maritime. Plusieurs épaves bien conservées de l'Antiquité classique et de l'ère moderne disposent d'un excellent potentiel pour la protection in situ et la présentation du patrimoine culturel sous-marin de la Croatie.

Mots-cles: archéologie subaquatique, archéologie maritime, épaves, navigation, patrimoine culturel, protection, préservation, Croatie

\section{Das Unterwasser-Kulturerbe und die Meeresarchäologie in Kroatien - ein Überblick}

Archäologische Fundplätze in den Flachwasserzonen Kroatiens werden seit dem 16. Jh. in schriftlichen Quellen erwähnt und seit dem 18. Jh. sind sie als Indiz des Absinkens der ostadriatischen Küste 
angeführt worden. Vom Ende des gleichen Jahrhunderts stammt auch der erste Bericht eines römischen Schiffswracks in kroatischen Gewässern. Schwamm- und Korallentaucher brachten archäologische Funde vom Meeresboden mit, was zum Aufbau vieler privater und kirchlicher Sammlungen beitrug. Einzelne Kampagnen, die auf einen Schutz des Unterwasser-Kulturerbes zielten, begannen in den 1950er Jabren und in den 1970ern wurden diese Bemühungen Teil eines woblorganisierten Systems. Wenngleich der Mangel systematischer Forschung noch immer beträchtlich ist, hat eine Anzabl von Prospektionen und Rettungsgrabungen unser Wissen zu früher Seefahrt entlang der kroatischen Küste bereichert und zur Untersuchung der marinen Umwelt beigetragen. Einige gut erhaltene Schiffswracks vom klassischen Altertum bis zur modernen Zeit besitzen ein exzellentes Potential für den in-situ-Schutz und die Präsentation des Unterwasser-Kulturerbes Kroatiens.

Stichworte: Unterwasserarchäologie, Meeresarchäologie, Schiffswracks, Seefahrt, Kulturerbe, Schutz, Erhaltung, Kroatien 